\title{
Peran Masyarakat dalam Menciptakan Budaya Hidup Bersih dari Sampah di Desa Kalijaga Selatan Lombok Timur
}

\author{
Nita Izul Fitri \\ Universitas Hamzanwadi \\ nita.izulfitri@gmail.com
}

\begin{abstract}
Abstrak
Tujuan dalam penelitian ini adalah untu mengetahui pengelolaan sampah di Desa Kalijaga Selatan Lombok Timur, mengetahui peran Masyarakat dalam mengelola sampah di DesaKalijaga Lombok Timur, dan mengetahui dampak pengelolaan sampah dengan terciptanya budaya hidup bersih pada masyarakat Desa Kalijaga Selatan Lombok Timur. Penelitian ini menggunakan metode deskriptif kualitatif. Teknik analisis data yang digunakan adalah teknik analisis model interaktif yang meliputi tiga kompenen penting, yakni reduksi data, penyajian data, dan penarikan kesimpulan. Hasil penelitian menunjukkan bahwa peran masyarakat Desa Kalijaga Selatan dalam mengelola sampah masih dengan cara sederhana, pengelolaan yang dilakukan masyarakat hanya sebatas mengumpulkan sampah anorganik untuk dijual ke pengepul sampah, selain itu masyarakat Desa Kalijaga Selatan juga melakukan pembakaran secara langsung di tepi jalan maupun di pekarangan rumah. Salah satu bentuk peran masyarakat dalam upaya perbaikan lingkungan yaitu dengan memberikan sumbangan tenaga berupa kerja bakti dan ikut serta dalam pengelolaan sampah.
\end{abstract}

Kata Kunci: Peran, Masyarakat, Pengelolaan, Sampah

\begin{abstract}
The purpose of this study is to find out waste management in South Kalijaga Village, East Lombok, to find out the role of the community in managing waste in Kalijaga Village, East Lombok, and to know the impact of waste management by creating a clean livin culture in the people of South Kalijaga Village, East Lombok. This study used descriptive qualitative method. The data analysis technique used is an interactive model analysis technique which includes three important components, namely data reduction, data presentation, and drawing conclusions. The results showed that the role of the people of South Kalijaga Village in managing waste was still in a simple way, the management carried out by the community was only limited to collecting inorganic waste to be sold to garbage collectors, besides that the people of South Kalijaga Village also burned directly on the side of the road or in the yard of the house. . One form of the community's role in efforts to improve the environment is by contributing labor in the form of community service and participating in waste management.
\end{abstract}

Keywords: Role, Community, Management, Waste 


\section{Pendahuluan}

Lingkungan hidup adalah kesatuan ruang dengan semua benda, keadaan, dan makhluk hidup yang mempengaruhi kelangsungan kehidupan dan kesejahteraan manusia serta makhluk hidup lainnya yang dapat mempengaruhi hidupnya (Siahaan, 2004). Lingkungan yang bersih adalah dambaan bagi semua orang. Kesehatan lingkungan merupakan faktor penting dalam kehidupan sosial masyarakat, bahkan kesehatan merupakan faktor yang dominan dalam kesejahteraan masyarakat. Apabila kesehatan masyarakat terganggu, maka produktivitas orang tersebut pun akan sedikit terganggu. Dalam melakukan suatu pekerjaan tentunya dibutuhkan kesehatan yang optimal, sehingga pekerjaan dapat berjalan lancar dan tentu hasilnya dapat maksimal. Salah satu faktor yang dapat mempengaruhi kualitas lingkungan adalah adanya pencemaran lingkungan.

Pencemaran lingkungan adalah masuknya atau dimasukkannya makhluk hidup, zat, energy, dan komponen lain ke dalam lingkungan hidup oleh kegiatan manusia sehingga kualitasnya turun sampai pada tingkat tertentu dan menyebabkan lingkungan hidup tidak berfungsi sesuai dengan peruntukannya (Alamsyah, 2013: 156-157). Kebersihan merupakan upaya manusia untuk memelihara diri dan lingkungannya dari segala yang kotor dan keji dalam rangka mewujudkan dan melestarikan kehidupan yang sehat dan nyaman (Yuliani \& Nazaruddin, 2014). Sampah adalah suatu yang tidak dikehendaki dan bersifat padat, sementara dalam Undang-undang Nomor 18 Tahun 2008 tentang pengelolaan sampah, disebutkan sampah adalah sisa kegiatan sehari-hari manusia atau proses alam yang berbentuk padat atau semi padat berupa zat organik atau non organik bersifat dapat terurai atau tidak dapat terurai yang dianggap sudah tidak berguna lagi dan dibuang ke lingkungan (Slamet, 2002: 15).

Dalam mewujudkan kebersihan lingkungan, masyarakat di Desa Kalijaga Selatan sebagai pelaku utama dalam membentuk budaya masyarakatnya sendiri dalam bersikap dan berperilaku terhadap penanganan sampah perlu mendapatkan perhatian yang lebih. Sikap dan perilaku yang kemudian membentuk sebuah kesadaran terhadap kebersihan lingkungan merupakan faktor penting dalam mewujudkan lingkungan yang bersih. Berpijak dari kondisi yang ada, untuk memecahkan masalah sampah harus melihat pola penanganan yang ada saat ini. Masalah sampah yang ada di Desa Kalijaga dapat dipecahkan dengan baik apabila peran aktif masyarakat meningkat, mengupayakan agar 
sampah dikelola, dipilah dan diproses tahap awal mulai dari timbunan sampah itu sendiri. Upaya ini setidaknya dapat mengurangi timbunan sampah.

Penelitian yang relevan dengan penelitian ini sekaligus juga memiliki keberbedaan dengan penelitian ini diantaranya adalah penelitian Bara, Lasut, \& Goni (2018) tentang peran disiplin masyarakat dalam menjaga budaya hidup bersih terhadap lingkungan di Desa Tuabatu Talaud. Kemudian ada penelitian Masitoh (2006) tentang tingkat kedisiplinan masyarakat dalam menjaga budaya hidup bersih terhadap lingkungannya, studi kasus pada masyarakat Banaran Semarang. Ada juga penelitian Sobry \& Naamy (2016) tentang penguatan ekonomi masyarakat melalui pengelolaan sampah dengan pendekatan keagamaan di Kelurahan Prapen Mataram. Selanjutnya ada penelitian Ariastuti, Astuti, \& Herawati (2015). Tentang berdamai dengan sampah. Penelitianpenelitian tersebut sejalan dengan penelitian ini tentang upaya masyarakat dalam mengelola sampah. Perbedaan terlihat pada pendekatan penelitian dan lokasi penelitian. Oleh karena itu tujuan yang akan dicapai pada penelitian ini adalah untuk mengetahui bagaimana pengelolaan sampah di Desa Kalijaga Selatan Lombok Timur, mengetahui peran masyarakat dalam mengelola sampah di Desa kalijaga Selatan Lombok Timur, dan mengetahui dampak pengelolaan sampah dengan terciptanya budaya hidup bersih pada masyarakat Desa Kalijaga Selatan Lombok Timur.

\section{Metode Penelitian}

Penelitian ini menggunakan metode deskriptif-kualitatif dimana penelitian ini fokus untuk menginterpretasikan objek penelitian sesuai dengan apa yang terjadi pada proses observasi di lapangan (Sukardi, 2005; Sugiyono, 2009). Sumber primer dalam penelitian didapatkan melalui observasi dan wawancara. Sedangkan sumber sekunder didapatkan melalui dokumentasi yang berhubungan dengan obyek yang diteliti.

Dalam penelitian ini, peneliti melakukan observasi sebanyak tiga kali dengan cara melihat langsung keadaan di lapangan. Peneliti melakukan observasi pertama pada tanggal 10 Mei 2019 tentang kondisi lingkungan masyarakat Desa Kalijaga Selatan mengenai kondisi fisik lingkungan yang meliputi rumah-rumah penduduk, halaman rumah dan juga lingkungan masyarakat. Observasi kedua peneliti lakukan pada tanggal 16 Mei 2019 tentang aktivitas masyarakat dalam menjaga kebersihan lingkungan yang 
ada di desa kalijaga Selatan. Kemudian observasi ketiga peneliti lakukan pada tanggal 20 Mei 2019 tentang perilaku dan sikap masyarakat Desa Kalijaga Selatan.

Wawancara yang mendalam tentang pengelolaan sampah dalam menciptakan budaya hidup bersih, peneliti harus memperhatikan pertanyaan-pertanyaan yang akan diajukan untuk responden agar sesuai dengan keadaan. Dalam pelaksanaannya peneliti akan melakukan wawancara kepada Kepala Desa dan mantan Kepala Desa Kalijaga Selatan dan tentang kondisi sosial masyarakat Desa Kalijaga Selatan, pengelolaan sampah, dan peran masyarakat dalam mengelola sampah. Selain itu, peneliti juga mewawancarai beberapa pegawai yang bekerja di Kantor Desa Kalijaga Selatan tentang pengelolaan sampah, peran masyarakat, dan dampak pengelolaan sampah dalam menjaga kebersihan pada masyarakat Desa Kalijaga Selatan. Wawancara yang dilakukan peneliti ini bertujuan untuk mengetahui pengelolaan sampah tersebut, peran masyarakat dalam mengelola sampah, dan dampak pengelolaan sampah dengan terciptanya budaya hidup bersih pada masyarakat Desa Kalijaga Selatan. Dalam penelitian ini dokumentasi dilakukan dengan cara mengumpulkan data yang diperlukan yaitu, data yang diperoleh dari hasil wawancara, data dari kegiatan observasi dan data monografi penduduk desa. Selain dokumen berupa data-data dari desa, peneliti juga mengambil data berupa foto tentang perilaku dan sikap masyarakat, serta kondisi lingkungan masyarakat Desa Kalijaga Selatan dalam menjaga kebersihan lingkungannya.

Teknik analisis data yang digunakan adalah teknik analisis model interaktif. Analisis model interaktif meliputi tiga kompenen penting, yakni reduksi data, penyajian data, dan penarikan kesimpulan. Proses analisis dilakukan untuk mengungkap secara lebih komprehensif tentang pengelolaan sampah berdasar teori yang digunakan.

\section{Pembahasan}

\section{Profil Desa Kalijaga Selatan Lombok Timur}

Gambaran umum masyarakat Desa Kalijaga Selatan dapat dilihat melalui kondisi geografis, kondisi demografi penduduk, dan keadaan sosial budaya masyarakat. Desa Kalijaga Selatan adalah salah satu Desa pemekaran dari Desa Kalijaga yang ada di wilayah Kecamatan Aikmel Kabupaten Lombok Timur yang didefinitifkan pada tanggal 22 Juni 2004 berdasarkan dengan peraturan daerah Kabupaten Lombok Timur Nomor 5 Tahun 2004 tentang Pembentukan. Desa Kalijaga Selatan berdasarkan ketinggian dari 
permukaan laut $194 \mathrm{~m}$ dengan luas 1,63 km² dengan jarak tempuh ke Kota Kecamatan sepanjang 6 km dan jarak tempuh ke Kota Kabupaten 20 km. Desa Kalijaga Selatan memiliki luas wilayah 162,289 Ha, dengan perincian luas areal pertanian 132,001 Ha, perkebunan15.062 Ha, permukiman 15.226 Ha, dengan jumlah penduduk 2.778 jiwa dan 858 kk (Monografi Desa, 2018).

Jumlah penduduk Desa Kalijaga Selatan Tahun 2017 mencapai 2471 jiwa. Apabila dirinci menurut jenis kelamin, penduduk Desa Kalijaga Selatan Tahun 2017 terdiri dari 1146 laki-laki dan 1325 perempuan. persentase jumlah penduduk menurut jenis kelamin baik laki-laki dan perempuan yang paling tinggi adalah jenis kelamin perempuan berjumlah 53,62\% sedangkan jumlah persentase jenis kelamin laki-laki 46,37\% (Profil Desa, 2018).

Masyarakat Desa Kalijaga Selatan adalah masyarakat yang religius dengan populasi warganya $100 \%$ beragama islam, dan kebudayaan islam sangatlah kental di Desa ini. Ini dapat dilihat dengan adanya Pondok Pesantren Darusshalihin NW yang bergerak dalam bidang pendidikan, mulai dari tingkat Taman Kanak-Kanak (TK) hingga Madrasah Aliyah (MA). Pada umumnya masyarakat Desa Kalijaga Selatan masih memegang teguh prinsip gotong royong dan saling tolong menolong di antara warga. Selain itu, di kalangan masyarakat Desa Kalijaga Selatan juga sudah mulai menerapkan nilai-nilai demokrasi, misalnya dalam menyelesaikan setiap permasalahan selalu dilakukan dengan cara musyawarah. Masyarakat Desa Kalijaga Selatan adalah masyarakat yang berbudaya dan berkarakter ramah tamah sesama warga. Masyarakat Desa Kalijaga Selatan sangat alami dan masih sangat kuat memegang tradisi nenek moyang mereka seperti yang masih berlaku di masyarakat adalah "melayat" yang dilakukan jika ada warga yang meninggal, mereka akan mengadakan acara selamatan atau begawe. Dalam hal ini warga memberikan sumbangan berupa beras bagi keluarga yang mendapatkan musibah kematian atau yang mengadakan gawe.

Adapun ritual yang dilakukan bagi yang mendapatkan musibah kematian yaitu, ritual pelayaran, pada dasarnya ritual pelayaran merupakan salah satu bagian dari ritual kematian yang dilaksanakan pada minggu kedua setelah nyiwaq. Adapun fungsi ritual pelayaran dalam kematian masyarakat yaitu mendoakan keselamatan secara berjamaah bagi masyarakat yang meninggal. Makna simbol yang terkandung dalam ritual pelayaran 
yaitu untuk menyambung silaturrahmi dan sebagai simbol gotong-royong warga dalam bermasyarakat.

\section{Pengelolaan Sampah di Desa Kalijaga Selatan Lombok Timur}

Dari hasil observasi yang telah peneliti lakukan pada tanggal 10 Mei 2019 bahwa asalah kebersihan lingkungan oleh masyarakat Desa Kalijaga Selatan, diidentikkan dengan masalah sampah yang juga berhubungan dengan perilaku masyarakat dalam menjaga kebersihan lingkungannya, karena sampah merupakan faktor utama yang dapat merusak atau menggangu kebersihan lingkungan dan kesehatan, akan tetapi hal itu justru kadang menjadi hal yang dilupakan oleh kebanyakan masyarakat. Hal ini dapat dilihat pada dokumentasi gambar yang diambil penelitia pada tanggal 10 Mei 2019 memperlihatkan kondisi pembuangan sampah di Desa Kalijaga Selatan.

Gambar 1. Keadaan Belakang Rumah Salah Satu Penduduk Desa Kalijaga Selatan

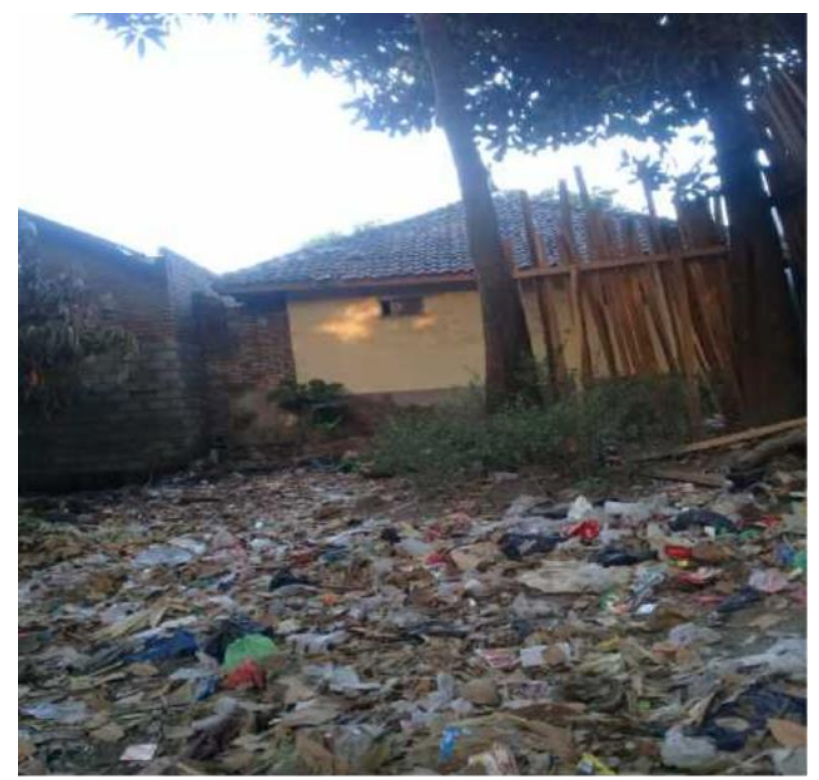

Sumber: Hasil Observasi Peneliti, 10 Mei 2019.

Selain sampah, perilaku masyarakatnya juga ikut mempengaruhi terbentuknya kebersihan lingkungan yaitu, kesadaran dan sikap tanggungjawab terhadap kondisi kebersihan lingkungan. Dalam hal ini umumnya masyarakat Desa Kalijaga Selatan 
menyikapi sampah dengan cara memanfaatkan pekarangan atau kebun untuk dijadikan tempat pembuangan sampah. Hal ini dapat dilihat dari dokumentasigambar di bawah ini.

Gambar 2. Penggunaan Lahan Kosong yang Dijadikan Tempat Pembuangan Sampah

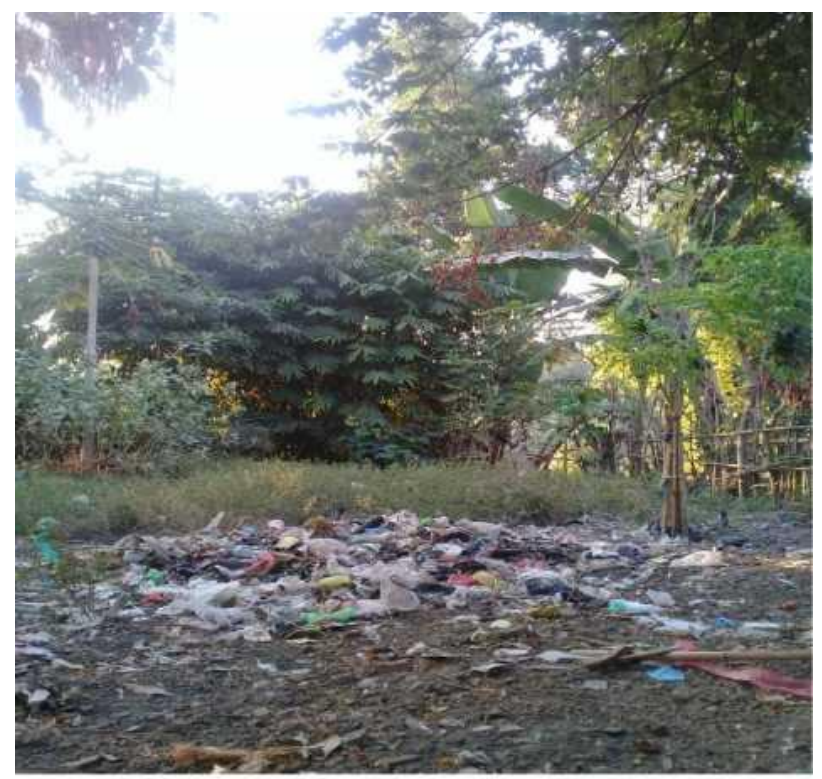

Sumber: Hasil Observasi Peneliti, 16Mei 2019

Dari hasil observasi yang telah peneliti lakukan pada tanggal 16 Mei 2019 tentang aktivitas masyarakat dalam menjaga kebersihan lingkungan di Desa Kalijaga Selatan masih banyak masyarakat yang membuang sampah sembarangan tempat yang tidak seharusnya, seperti membuang sampah di jalan raya dan tanah yang kosong sehingga masih banyak sampah yang berserakan. Hal inilah yang menimbulkan kekecewaan kepada aparat RT, Kadus dan lain-lain (Observasi, 16 Mei 2019). Menurut Kadus Menak Selatan dijelaskan bahwa itu merupakan perbuatan yang kurang baik, perlu adanya pembinaan dan pemahaman kepada masyarakat tentang pentingnya kebersihan lingkungan, mirisnya masyarakat yang membuang sampah di Desa Kalijaga Selatan bukan hanya dari warga Desa Kalijaga Selatan saja melainkan dari warga luar (Wawancara, Rusli, 16 Mei 2019).

Warga yang membuang sampah selain dari warga luar juga dari status sosial yang berbeda seperti pedagang, warga yang akan berangkat kerja. Meskipun di jalan raya sudah dipasang plang peringatan untuk tidak membuang sampah secara sembarangan tetapi sampah tersebut tetap saja berserakan di tempat yang tidak seharusnya. Sampah bukan saja dari bahan yang mudah diolah tetapi ada juga sampah yang tidak mudah diolah. Masing-masing dari ketua RT sudah mengusahakan dengan cara memberikan 
informasi kepada masyarakat untuk tidak membuang sampah sembarangan dan dari pihak Kepala Desa sudah mengadakan rapat Desa kepada semua RT untuk membuat perjanjian bagi yang membuang sampah secara sembarangan akan dikenakan denda sebanyak seratus ribu.

Pengelolaan sampah merupakan perlakuan terhadap sampah yang bertujuan untuk memperkecil atau menghilangkan masalah-masalah yang berkaitan dengan lingkungan. Tahapan pengelolaan sampah terdiri atas: pengumpulan, pengangkutan dan pemusnahan yang masing-masing sistem sangat mempengaruhi keberhasilan pengelolaan sampah di suatu Desa. Sebelum diangkut oleh petugas kebersihan, sampah ditampung sementara dalam wadah. Tahap ini disebut tahap penampungan sampah. Di masyarakat tempat penampungan sampah ada yang dibuat secara permanen yaitu dari bahan yang berupa batu bata atau semen. Wadah yang digunakan untuk menampung sampah haruslah memiliki kriteria utama yaitu, mudah dibersihkan, tidak mudah rusak, dapat ditutup rapat, dan ditempatkan di luar rumah. Keempat hal tersebut harus terpenuhi secara baik.

Pewadahan merupakan suatu cara penampungan sampah sementara secara individual maupun komunal. Tujuan dilakukan pewadahan yaitu memudahkan pengumpulan dan pengangkutan, mengatasi timbulnya bau busuk dan menghindari perhatian dari binatang, menghindari air hujan dan menghindari pencampuran sampah. Untuk saat ini yang dilakukan di Desa Kalijaga Selatan adalah individual dan terbatas. Wadah-wadah individual ini ditempatkan di depan rumah masing-masing.

Desa Kalijaga Selatan dalam mengelola sampah masih dengan cara sederhana yaitu sampah dikumpulkan, diangkut kemudian dibuang ke TPA (Tempat Pembuangan Akhir) oleh petugas kebersihan. Sampah organik dan non organik yang tercampur dibuang begitu saja dalam wadah dan kemudian dipindahkan ke tempat pembuangan sampah (TPS) menggunakan mobil setiap hari minggu untuk diangkut menuju TPA. Kondisi pengelolaan sampah seperti itu akan memberatkan beban TPA dengan lahan yang terbatas. Hal tersebut akan mengakibatkan sampah tidak dapat terkelola dengan baik.

Berdasarkan dari hasil wawancara yang telah dilakukan dengan salah satu tokoh masyarakat Desa Kalijaga Selatan dikatakan bahwa:

Tempat pembuangan akhir (TPA) ini merupakan tempat yang disediakan untuk membuang sampah dari semua hasil pengangkutan untuk diolah lebih lanjut, jadi tempat pembuangan akhir adalah tempat pengolahan sampah. Di mana TPA ini dimanfaatkan oleh warga Desa Kalijaga Selatan untuk membuang sampah yang telah terkumpul baik itu sampah organik maupun anorganik. Warga terkadang lupa 
untuk memilih sampah organik dan anorganik, sehingga bisa dikatakan itu akanmenjadi beban bagi TPA karna banyak sampah yang menumpuksedangkan lahannya terbatas untuk menampung semua sampah. Dan seandainya warga rajin untuk memilih sampah-sampah tersebut sebelum dibuang ke TPA pastinya tidak akan menjadi beban bagi TPA tersebut atau sampah- sampah tersebut tidak menumpuk begitu banyak (Wawancara, Nurdin, 28 Mei 2019).

Sedangkan saat diwawancarai tentang pengelolaan sampah tersebut, salah satu tokoh masyarakat mengemukakan bahwa hal yang paling sulit dilakukan dalam pengelolaan sampah yaitu, memilah sampah organik dan anorganik pada saat sampah itu dibuang oleh warga (Wawancara, Nurdin, 25 Mei 2019). Dijelaskan bahwa warga ini bisa kita katakan agak malas untuk memilih sampah anorganik, karena mereka tidak tahu kalau sampah anorganik itu bisa dimanfaatkan kembali dan kurangnya kesadaran mereka serta pengetahuan mereka dalam mengelola sampah. Dengan demikian itulah yang menjadikan kenapa sampah itu sulit untuk dikelola dengan baik oleh masyarakat disini (Wawancara, Nurdin, 25 Mei 2019).

Sampah yang ada di lingkungan rumah warga terdiri dari dua jenis yaitu sampah organik dan anorganik. Di mana sampah organik adalah sampah basah yang ada di rumah seperti sayuran, sedangkan sampah anorganik adalah sampah-sampah yang dapat didaur ulang seperti botol, kaleng dan yang lainnya. Selama ini sampah dianggap sesuatu yang tidak berguna sehingga harus dibuang. Padahal sampah dapat menjadi sesuatu yang berguna apabila seseorang rajin memilihnya. Masyarakat Desa Kalijaga Selatan dalam hal mengelola sampah dinilai masih belum terbiasa memilih dan memilah sampah organik dan anorganik sebelum dibuang ke tempat sampah. Padahal jika sampah telah dipilih sesuai jenisnya maka hal itu tentu akan lebih memudahkan petugas dalam proses pemusnahan atau pengelolaannya.

Sejalan dengan wawancara terhadap tokoh masyarakat di atas, hasil wawancara peneliti dengan petugas kebersihan Desa Kalijaga Selatan mengatakan bahwa masyarakat Desa Kalijaga Selatan terkadang lupa untuk memisahkan jenis sampah organik dan anorganik, padahal pemilihan sampah tersebut bertujuan untuk mempermudah proses daur ulang. Kurangnya kesadaran masyarakat dalam memilih sampah sesuai jenisnya menjadi suatu kebiasaan yang sulit untuk dirubah oleh masyarakat di Desa Kalijaga Selatan (Wawancara, Takiudin,28 Mei 2019).

Pnjelasan di atas menunjukkan bahwa masyarakat Desa Kalijaga Selatan dalam melakukan pengelolaan sampah masih dengan cara yang sederhana yaitu, dengan cara 
dijual ke pengepul sampah. Selain itu masyarakat Desa Kalijaga Selatan juga melakukan pembakaran sampah. Kebiasaan masyarakat dalam memilih sampah juga masih minim karena mereka belum sepenuhnya memiliki pengetahuan untuk mengelola sampah dengan baik. Selain itu, masyarakat Desa Kalijaga Selatan menganggap kalau sampah itu tidak berguna lagi sehingga Masyarakat dengan mudah untuk membuangnya begitu saja.

Sampah merupakan bahan sisa, baik bahan-bahan yang tidak digunakan lagi (barang bekas) maupun bahan yang sudah diambil bagian utamanya yang dari segi ekonomis, sampah adalah bahan buangan yang tidak ada harganya dan dari segi lingkungan, sampah adalah bahan buangan yang tidak berguna dan banyak menimbulkan masalah pencemaran dan gangguan pada kelestarian lingkungan (Hadiwiyoto, 1983: 12; Proverawati, dan Rahmawati 2012). Seperti halnya dengan masyarakat yang ada di Desa Kalijaga Selatan, bahwa sampah yang ada di lingkungan mereka itu terlihat memperihatinkan karena mereka sangat acuh dengan yang namanya sampah dan bahkan mereka sangat merasa gengsi untuk memungut sampah. Sehingga keadaan lingkungan yang ada di Desa Kalijaga Selatan menjadi kotor dan sedikit tercemar oleh bau busuk yang berasal dari perilaku masyarakat yang membuang sampah sembarangan. Masyarakat belum bisa mejaga kelestarian lingkungan tersebut, bahkan mereka tidak tahu bahwa sampah itu bisa menjadi sumber penyakit.

Salah satu informan yang bernama mengatakan bahwa kami sebagai warga yang bertempat tinggal di sini tentu menginginkan Desa kami ini menjadi Desa yang bersih dari sampah sehingga kami selaku warga Desa Kalijaga Selatan perlu mendapatkan bimbingan yang khusus dalam hal pengelolaan sampah, dan jika kita bandingkan dengan tahun-tahun yang sebelumnya jauh lebih baik yang sekarang. Karena sekarang sebagian dari kami sudah peduli dengan kebersihan lingkungan (Wawancara, Diani, 28 Mei 2019). Informan lain menjelaskan bahwa sebagai kepala Lingkungan di sini dengan melihat permasalahan sampah yang ada sudah dilakukan penyuluhan terhadap warga dalam hal pengelolaan sampah (Wawancara, Rusli B, 28 Mei 2019). Informan lain juga mengatakan bahwa setelah adanya penyuluhan, sebagaian dari warga Desa Kalijaga Selatan sudah meluangkan waktunya untuk memilih sampah tersebut kemudian bisa untuk dimanfaatkan menjadi sesuatu yang bernilai ekonomis" (Wawancara, Rusli C, 28 Mei 2019). 
Lingkungan yang bersih merupakan hal yang diinginkan oleh semua orang terutama masyarakat Desa Kalijaga Selatan. Sebenarnya masyarakat Desa Kalijaga Selatan tentu berharap bisa mengelola sampah dengan baik, akan tetapi fasilitas yang dimilikinya belum memadai sehingga mereka menjadi malas untuk memilih sampah tersebut. Upaya masyarakat dalam menjaga kebersihan lingkungan dilakukan dengan cara membersihkan rumah masing-masing, untuk masalah sampah upaya yang dilakukan masyarakat hanya membakar nya saja tanpa adanya tindakan lanjutan seperti mendaur ulang sampah tersebut. Hal ini disebabkan karena kurangnya pengetahuan dan kesadaran masyarakat tentang kebersihan dan hidup sehat sehingga membuat lingkungan tidak bersih dan terjaga.

Proses sosialisasi pengelolaan sampah meliputi proses sosialisasi kepada masyarakat, forum yang dipakai untuk menyampaikan atau mensosialisasikan yaitu, dalam pertemuan PKK, pertemuan pemuda, pertemuan RT, RW dan sebagainya. Dalam kegiatan sosialisasi ini peran serta masyarakat dilihat dari keikutsertaan masyarakat dalam mengikuti kegiatan sosialisasi. Sosialisasi ini dilaksanakan dengan tujuan untuk menumbuhkan kesadaran pribadi dari masyarakat dalam pengelolaan sampah. Dari hasil wawancara pada warga Desa Kalijaga Selatan dalam mengikuti kegiatan penyuluhan, peran serta masyarakat sedikit membaik, karena diatas 50\% Warga Desa Kalijaga Selatan cukup antusias dalam melaksanakan kerja bakti. Sedangkan warga Desa Kalijaga Selatan karena keterbatasan lokasi yang naik turun dan TPS yang cukup jauh yang tentu menyulitkan bagi warga untuk menyediakan tempat sampah di depan rumah masing-masing. Sehingga masyarakat Desa Kalijaga Selatan memanfaatkan pekarangan rumah untuk membuang sampah tersebut. Sikap terjadi berdasarkan kesadaran yang melandasi aksi atau perbuatan seseorang. Begitu pula dengan sikap masyarakat Desa Kalijaga Selatan terhadap pemilihan sampah sebagai suatu kesadaran yang harus dimiliki.

Disampaikan oleh seorang informan bahwa masyarakat dalam sikapnya mengelola sampah dipengaruhi oleh interaksi sosial. Di sini berlaku asumsi bahwa antara perilaku masyarakat yang satu dengan yang lain akan saling mempengaruhi, artinya, sebenarnya ada sebagaian dari masyarakat yang memiliki pengetahuan tentang pengelolaan sampah dan melakukan pemilihan sampah, tetapi karena lingkungan tempat kami tinggal tersebut tidak mendukung maka perilaku pemilihan sampah jarang dilakukan (Wawancara, 
Ahmad Saoki, 28 Mei 2019). Senada dengan itu, informan lain mengatakan bahwa selama saya menjabat sebagai Kepala Desa di dalam pengelolaan sampah, saya sudah melakukan upaya untuk menangani sampah tersebut dengan cara melakukan penyuluhan kepada masyarakat tentang bagaimana mengelola sampah dengan baik (Wawancara, Rusli A, 28 Mei 2019).

Sebagian dari masyarakat Desa Kalijaga Selatan memiliki pengetahuan dalam memilah sampah hanya saja fasilitasnya tidak memadai untuk mengelola sampah tersebut. Di mana masyarakat Desa Kalijaga Selatan dalam hal pengelolaan sampah masih dengan cara yang sangat sederhana yaitu masyarakat hanya bisa mengumpulkan sampah tersebut lalu dijual ke pengepul sampah, selain itu masyrakat juga terkadang melakukan pembakaran terhadap sampah-sampah tersebut. Dengan demikian, penyuluhan yang dilakukan kepada masyarakat Desa Kalijaga Selatan tersebut adalah hal yang penting sekali untuk dilakukan karena itu akan merubah Desa menjadi lebih baik dari sebelumnya.

\section{Peran Masyarakat dalam Mengelola Sampah di Desa Kalijaga Lombok Timur}

Bentuk kedisiplinan masyarakat Desa Kalijaga Selatan dalam menjaga kebersihan lingkunga dapat dilihat dari sikap dan perilaku masyarakatnya. Dalam hal ini masyarakat Desa Kalijaga Selatan belum memiliki sikap disiplin dalam menjaga kebersihan lingkungan. Hal itu dapat dilihat dari ketidakteraturan masyarakat dalam membersihkan lingkungan serta perilaku masyarakat yang kurang peduli dengan kondisi kebersihan di lingkungan yang ada. Kurangnya sikap disiplin masyarakat dalam menjaga kebersihan lingkungan juga disebabkan oleh minimnya pemahaman dan pengetahuan, serta perilaku yang berbeda mengenai kebersihan lingkungan. Sehingga mengakibatkan sulitnya masyarakat untuk memiliki kedisiplinan dalam menjaga budaya hidup bersih. Selain hal itu kurangnya kepedulian masyarakat terhadap kondisi lingkungan masyarakat juga menjadi faktor penghalang terbentuknya sikap disiplin dalam menjaga kebersihan.

Mengenai masalah tersebut bahwa masalah kebersihan lingkungan merupakan salah satu indikator untuk mengukur tingkat kedisiplinan dalam kehidupan sosialnya dilingkungan masyarakat. Lingkungan yang bersih dapat terwujud apabila dalam sikap dan perilaku individu dalam masyarakat peduli terhadap alam sekelilingnya (Proverawati dan Rahmawati 2012). Sikap dan perilaku demikian itu biasanya lahir dan dilatar belakangi oleh tingkat pengetahuan, kesadaran dan tingkat disiplin pribadi di tengah- 
tengah kehidupan masyarakat (Soekanto, 1983). Di samping itu kebiasaan hidup yang bersih dan tertib merupakan hasil dari proses panjang trasformasi sistem nilai, baik nilai budaya maupun agama. Untuk memiliki sikap disiplin dalam mewujudkan kebersihan dan menerapkan budaya hidup bersih di masyarakat, perlu kesadaran diri untuk bertindak dan berperilaku (Notoatmodjo, 2007).

Berdasarkan hasil observasi yang telah peneliti lakukan pada tanggal 20 Mei 2019 bahwa masyarakat Desa Kalijaga Selatan tetap berupaya untuk menjaga kebersihan lingkungan melalui kegiatan kerja bakti yang dilakukan atas kesepakatan bersama. Sikap dan perilaku ini dapat dianut berdasarkan keyakinan bahwa hal itulah yang benar bermanfaat bagi diri sendiri dan masyarakat. Dalam hal ini masyarakat Desa Kalijaga Selatan dalam melakasanakan kegiatan menjaga kebersihan adalah karena adanya rasa tangungjawab serta kesadaran untuk bertindak (Observasi, 20 Mei 2019).

Kedisiplinan masyarakat Desa Kalijaga Selatan dalam menjaga kebersihan lingkungan tidak tumbuh dengan sendirinya, melainkan ada upaya untuk menumbuhkan sikap dan perilaku dalam menjaga kebersihan lingkungan yaitu melalui pendidikan dalam keluarga yang dilakukan oleh orang tua yaitu dengan cara menanamkan nilai, sikap dan kebiasaan kepada anaknya pada waktu masih kecil untuk belajar membiasakan agar selalu menjaga kebersihan baik melalui perintah, contoh atau teladan dari orang tua, kegiatan kerjabakti. Walaupun demikian faktor kondisi lingkungan masyarakat juga ikut mempengaruhi perilaku masyarakat dalam menjaga budaya hidup bersih. Disiplin lahir, tumbuh dan berkembang dari sikap seseorang di dalam sistem nilai budaya yang telah ada di dalam masyarakat. Perilaku masyarakat Desa Kalijaga Selatan untuk menjaga kebersihan lingkungan yang diwujudkan melalui kegiatan kerja bakti sebagai wujud partisipasi masyarakat dalam menjaga kebersihan lingkungan, yang dilaksanakan atas dasar rasa tangungjawab serta kesadaran masyarakat setelah adanya penyuluhan dari aparat Desa.

Sikap dan tanggung jawab dalam hal ini merupakan kesadaran manusia akan tingkah laku atau perbuatannya, baik yang disengaja maupun yang tidak disengaja. Dengan begitu tangung jawab dapat diartikan sebagai sebagai perwujudan kesadaran dan kewajiban yang disertai dengan tindakan atau perilaku (Observasi, 20 Mei 2019). Dengan demikian menjaga lingkungan merupakan tanggung jawab dan kewajiban kita sebagai manusia. Sikap dan perilaku masyarakat Desa Kalijaga Selatan terhadap 
kebersihan lingkungan tidak lepas dari kondisi lingkungan. Di mana kondisi lingkungan di wilayah Desa Kalijaga Selatan sebagian besar yang dijadikan tempat tinggal atau pemukiman masyarakat berada di lingkungan pekarangan yang luas, sehingga memungkinkan masyarakat Desa Kalijaga Selatan memiliki perilaku dan kebiasaan untuk memanfaatkan lahan pekarangan yang ada sebagai tempat pembuangan sampah. Selain hal itu perilaku masyarakat juga dipengaruhi oleh kurangnya pengetahuan yang dimiliki oleh masyarakat setempat. Hal ini senada dengan yang disampaikan oleh informan bahwa pada kenyataanya masyarakat tidak dapat lepas dari lingkungan, ia harus dapat menyesuaikan diri dengan sifat lingkungan, namun juga dapat mempengaruhi lingkungan di mana mereka hidup (Wawancara, Sa'gap, 20 Mei 2019).

Pada umumnya manusia lebih dipengaruhi oleh keadaan lingkungan, dan dalam tingkah lakunya dipengaruhi oleh keadaan lingkungan. Artinya bahwa perilaku masyarakat Desa Kalijaga Selatan dalam menjaga kebersihan lingkungan terbentuk dari sikap serta kebisaaan yang sudah ada di lingkungan masyarakat. Sebagian besar masyarakatnya memiliki kebiasaan yang sama dalam menyikapi masalah kebersihan lingkungan serta kebiasaan dalam menyikapi sampah dengan memanfaatkan lahan yang ada di sekitar mereka untuk dijadikan tempat pembuangan sampah. Dalam pengelolaan sampah harus ada kerjasama antara pemerintah dan masyarakat, agar tujuan pengelolaan dapat berhasil sesuai yang diharapkan dalam mendukung terciptanya lingkungan yang sehat dan bersih. Keduanya harus mampu menciptakan sinergi, tanpa melibatkan masyarakat, pemerintah tidak akan dapat mencapai hasil pembangunan secara optimal. Peran serta masyarakat dalam pengelolaan sampah merupakan kesediaan masyarakat untuk membantu berhasilnya program pengembangan pengelolaan sampah sesuai dengan kemampuan setiap orang tanpa berarti mengorbankan kepentingan diri sendiri (Djoyomartono, 2004). Tanpa adanya peran serta masyarakat semua program pengelolaan yang direncanakan akan sia-sia.

Hal yang sama juga disampaikan oleh Ralp Lintion bahwa masyarakat merupakan setiap kelompok manusia yang telah hidup dan bekerja bersama cukup lama sehingga mereka dapat mengatur diri mereka dan menganggap diri mereka sebagai suatu kesatuan sosial dengan batas- batas yang dirumuskan dengan jelas. Begitu juga dengan masalah kebersihan lingkungan, Mengenai peranan masyarakat tentang kebersihan lingkungan secara umumnya memandang kebijakan pemerintah antara masyarakat dengan 
suatu kesatuan yang sistemnya akan berkesinambungan apabila kebijakan pemerintah membuat peraturan daerah dengan ketentuan- ketentuannya dijalankan dan dipatuhi oleh semua masyarakatnya (Soekanto, 2006).

Pemerintah Desa Kalijaga Selatan dalam menjalankan perannya terus melakukan upaya atau perbaikan dalam menangani masalah sampah tersebut. Dalam penanganan sampah tersebut tentu pemerintah Desa selalu bekerja sama dengan masyarakat. Memang dalam penanganan ini pemerintah Desa memerlukan waktu yang lama dan ini pun menjadi perhatian penting dari pemerintah. Dari tahun ke tahun pemerintah Desa selalu berusaha melakukan perbaikan lingkungan. Seperti yang telah dilakukan yaitu dengan membentuk para petugas kebersihan dan juga pemerintah Desa memberikan lahan kepada masyarakat Desa Kalijaga Selatan untuk digunakan sebagai tempat membuang sampah. Seperti yang disampaikan oleh informan bahwa petugas kebersihan berperan dalam menangani masalah sampah tersebut, setiap hari minggu pagi saya sudah melakukan tugas saya sebagai petugas yang diberi kepercayaan oleh Pemerintah Desa untuk mengangkut semua sampah-sampah yang telah terkumpul dengan menggunakan mobil dan dibawa ke Tempat Pembuangan Akhir (TPA) (Wawancara, Takiudin, 28 Mei 2019). Hal ini juga disampaikan oleh salah satu informan bahwa upaya yang sudah saya lakukan sebagai kepala lingkungan pada masyarakat Desa Kalijaga Selatan untuk mewujudkan kebersihan lingkungan, yaitu dengan memberikan himbauan dengan cara mengadakan kegiatan kerja bakti kebersihan desa berdasarkan kesepakatan bersama, yang dilaksanakan pada satu kali sebulan. Untuk menggiatkan masyarakat, dan ada sanksi atau denda seratus ribu, apabila masyarakat dilihat membuang sampah secara sengaja oleh aparat kebersihan Desa" (Wawancara, Rusli, 28 Mei 2019).

Berdasarkan penjelasan informan di atas, bahwa para petugas kebersihan dan selaku kepala lingkungan sudah menjalankan perannya. Di mana Kepala Ligkungan dalam upaya menjaga kebersihan sudah menghimbaukan kepada masyarakat Desa Kalijaga Selatan untuk melakukan kerja bakti satu kali sebulan dan untuk menggiatkan masyarakat kepala lingkungan juga menerapkan sanksi apabila dilihat membuang sampah secara sembarangan. Dengan demikian, upaya yang sudah dilakukan oleh kepala lingkungan tentu sudah menjadi kewajiban bagi masyarakat untuk mengikuti aturan yang dibuat demi terciptanya lingkungan yang bersih. 
Masyarakat Desa Kalijaga Selatan dalam menjalankan perannya sebagai warga dalam hal menjaga kebersihan lingkungan dengan cara mengikuti aturan yang berlaku. begitu juga menurut Notoatmodjo (2007) bahwa peran masyarakat adalah ikut sertanya seluruh anggota masyarakat dalam memecahkan permasalahan-permasalahan masyarakat tersebut. Dalam hal ini partisipasi masyarakat Desa Kalijaga Selatan di dalam menciptakan budaya hidup bersih berarti keikutsertaan seluruh anggota masyarakat dalam memecahkan setiap permasalahan. Masyarakat Desa Kalijaga Selatan juga sudah bisa dilihat tingkat kesadarannya dalam membuang sampah karena mereka merasa bingung untuk membuang sampah tersebut dengan melihat banyaknya tumpukan sampah. Masyarakat juga melakukan kerja bakti dalam menjalankan perannya demi merubah lingkungan yang kotor menjadi bersih.

Pembangunan melalui partisipasi masyarakat merupakan salah satu upaya untuk pemerdayaan potensi masyarakat dalam merencanakan pembangunan yang berkaitan dengan sumber daya lokal berdasarkan kajian musyawarah, yaitu peningkatan aspirasi berupa keinginan dan kebutuhan nyata yang ada dalam masyarakat, peningkatan motivasi dan peran serta kelompok masyarakat dalam proses pembangunan (Alamsyah dan Ratna, 2013). Prinsip kerja dari pembangunan melalui partisipasi masyarakat adalah program kerja disampaikan secara terbuka kepada masyarakat dengan melakukan komunikasi partisipatif agar mendapat dukungan masyarakat. Program kerja dilakukan melalui kerjasama kelompok masyarakat, pejabat kelurahan dan segenap warga untuk memperkecil hambatan, Koordinasi selalu dilakukan baik secara vertikal maupun horizontal.

Dengan demikian, proses pengambilan keputusan berusaha dilakukan dengan benar-benar memperhatikan aspirasi masyarakat, sehingga dapat menunjukkan sebuah proses dan pengelolaan sampah yang aspiratif dan partisipatif. Dengan kata lain pengelolaan sampah bukan saja program pemerintah melainkan sebuah program yang juga program masyarakat. Hal ini sudah barang tentu mendorong warga untuk lebih serius dan kosisten terhadap keputusan yang telah disepakati antar pengurus dan warga di lingkungan sekitarnya. Hal ini dapat dilihat dari dokumen gambar hasil observasi di bawah ini. 
Gambar 3. Pembuatan tong sampah dalam kegiatan kerja bakti Desa Kalijaga Selatan

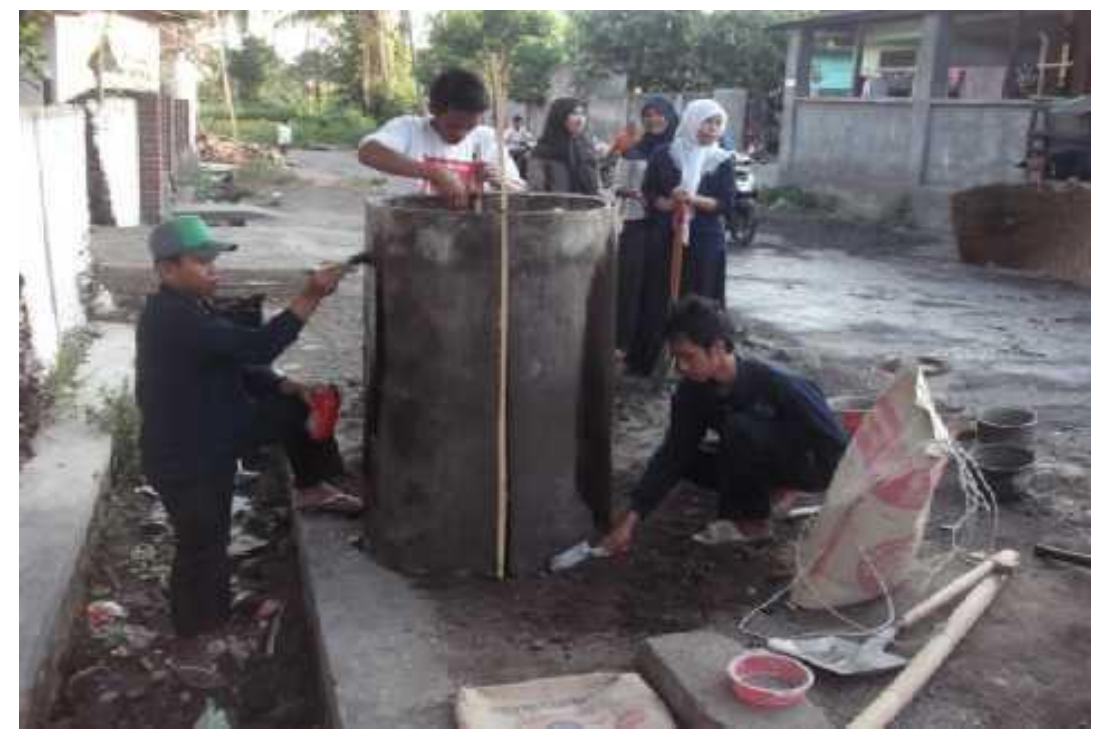

Sumber: Hasil Observasi Peneliti, Mei 2019

Dari hasil penelitian melalui kegiatan wawancara dan pengamatan yang diadakan langsung di lapangan mengenai perilaku masyarakat dalam menjaga kebersihan lingkungan masyarakat Desa Kalijaga Selatan pada kenyataannya belum sepenuhnya dapat dilaksanakan oleh masyarakat setempat, walaupun kegiatan kerja bakti merupakan peraturan atas keputusan bersama, akan tetapi pada kenyataannya kegiatan kerja bakti di lapangan tidak sesuai dengan pernyataan tersebut. Hal ini disebabkan karena adanya faktor kurangnya pemahaman masyarakat terhadap kesehatan dan kebersihan lingkungan. selain itu kurangnya fasilitas untuk mengelola sampah juga bisa mempengaruhinya. Masyarakat Desa Kalijaga Selatan dalam menjaga kebersihan lingkungannya bukan didasarkan atas kesadaran hati atau atas dasar inisiatif sendiri untuk bertindak dalam kegiatan partisifasi masyarakat di Lingkungannya. Dengan demikian maka pada umumnya masyarakat belum sepenuhnya memiliki sikap kesadaran dan tanggungjawab terhadap kebersihan lingkungan.

Pemerintah Desa menunjukkan rasa kepeduliannya terhadap masyarakat Desa Kalijaga Selatan dengan cara memberikan sarana dan prasarana kebersihan. Selain para petugas kebersihan atau kader-kader Desa yang berperan dalam hal menjaga kebersihan lingkungan, kami juga sebagai warga ikut berpartisifasi dalam hal tersebut. Di mana bentuk partisifasi kami berupa kerja bakti. Dampak lain yang dapat memberikan motivasi tambahan bagi kami dalam pengelolaan sampah adalah dari aspek ekonomi, dimana 
penjualan sampah anorganik yang dapat dijual kembali ke pengepul sampah akan dapat menambah pendapatan kita (Wawancara, Nurlaeli, 28 Mei 2019).

Berdasarkan uraian di atas bahwa dampak dari pengelolaan sampah tersebut sangat penting untuk dipertimbangkan, setelah mengetahui dampak yang ditimbulkan dari pengelolaan sampah tersebut seperti dampak dari segi kesehatan, ekonomi, lingkungan, dan sosial budaya tentunya ini merupakan masalah yang harus benar-benar dipedulikan. Dalam menjaga kebersihan Desa selain dari petugas kebersihan masyarakat juga ikut berpartisifasi dalam hal tersebut. Di mana bentuk partisifasi dari masyarakat tersebut berupa kerja bakti. Kondisi kebersihan lingkungan masyarakat Desa Kalijaga Selatan belum dapat sepenuhnya dikatakan sebagai lingkungan pemukiman yang bersih. Hal ini disebabkan masih banyaknya sampah dan ketidak teraturan masyarakat dalam menangani kebersihan lingkungan yang ada di sekitar mereka. Selain itu juga disebabkan pula oleh faktor perilaku masyarakat Desa Kalijaga Selatan yang pada umumnya dalam pemahaman kebersihan lingkungan belum sesuai dengan kenyataan yang ada di lingkungan.

Mengenai pengelolaan sampah sampai saat ini masih menjadi permasalahan di Desa Kalijaga, apabila sampah tidak dilakukan dengan pengelolaan yang baik maka akan menimbulkan masalah misalnya terjadinya pencemaran lingkungan seperti bau busuk sehingga menimbulkan penyakit. Timbunan sampah yang tidak terkendali akibat aktivitas masyarakat yang ada di Desa Kalijaga Selatan akan berdampak pada permasalahan lingkungan seperti menurunnya keindahan Desa, timbulnya bau dari pembusukan sampah, terjadinya pencemaran udara akibat pembakaran sampah yang mengganggu kesehatan masyarakat dan menjadi sumber penyakit bagi kesehatan manusia. Kondisi saat ini mencerminkan bahwa kesadaran masyarakat di Desa Kalijaga Selatan Kecamatan Aikmel terhadap penanganan sampah masih rendah, masyarakat Desa Kalijaga Selatan belum menganggap sampah sebagai suatu sumber daya, masyarakat juga belum banyak yang mengetahui informasi tentang berbagai pengelolaan sampah dan hanya sebagian kecil masyarakat yang mengetahuinya.

Desa Kalijaga Selatan dalam mengelola sampah masih dengan cara sederhana yaitu sampah dikumpulkan, diangkut kemudian dibuang ke TPA (Tempat Pembuangan Akhir) oleh petugas kebersihan. Sampah organik dan anorganik yang tercampur dibuang begitu saja dalam wadah dan kemudian dipindahka ke tempat pembuangan sampah (TPS) 
menggunakan mobil setiap hari minggu untuk diangkut menuju TPA. Kondisi pengelolaan sampah seperti itu akan memberatkan beban TPA dengan lahan yang terbatas. Hal tersebut akan mengakibatkan sampah tidak dapat terkelola dengan baik.

Peran masyarakat di Desa Kalijaga Selatan dalam mereduksi sampah masih belum terlihat, sedangkan kegiatan mereduksi sampah yang dilakukan oleh pemulung di TPS Desa Kalijaga Selatan masih sangat kecil. Oleh karena itu perlu dilakukan perencanaan mengenai pengelolaan sampah di Desa Kalijaga Selatan tersebut. Sehingga dapat membantu dalam mewujudkan sistem pengelolaan sampah yang baik di Desa Kalijaga Selatan. Selain itu, Pengelolaan sampah yang dilakukan oleh masyarakat di Desa Kalijaga Selatan hanya sebatas mengumpulkan sampah anorganik untuk dijual ke pengepul sampah yang dianggap memiliki nilai ekonomi, dan selain itu juga masyarakat Desa Kalijaga Selatan melakukan pembakaran sampah secara langsung di tepi jalan maupun pekarangan rumah, karena tidak tersedianya tempat pembuangan sampah yang memadai untuk menampung semua sampah rumah tangga yang ada di masyarakat Desa Kalijaga Selatan Kecamatan Aikmel.

Sistem pengumpulan sampah yang dilakukan oleh masyarakat Desa Kalijaga Selatan belum sepenuhnya baik. Hal tersebut dapat dilihat dari sampah yang dibuang oleh masyarakat kawasan tersebut, untuk membuangnya masyarakat tidak memisahkan antara sampah organik dan non organik. Meningkatnya timbunan sampah tanpa sistem pengelolaan yang tepat diperkirakan menjadi alasan tidak terciptanya lingkungan yang bersih, disebabkan masih banyak sampah yang berhamburan di jalan dengan tidak adanya tempat fasilitas pembungan sampah yang memadai, selain itu masyarakat di Desa Kalijaga Selatan membuang sampah di parit-parit.

Dengan memperhatikan gejala-gejala dan fakta-fakta yang nyata yang terlihat di lingkungan Desa Kalijaga Selatan pada penelitian ini, upaya yang hendak ditempuh adalah bahwa perilaku hidup yang bersih perlu ditingkatkan dengan cara sosialisasi terlebih dahulu terhadap masyarakat Desa Kalijaga Selatan terkait akan pentingnya menjaga kebersihan lingkungan. Selain itu program- program yang ada di Desa Kalijaga Selatan itu harus dijalankan dengan baik. Adapun program-program yang ada di Desa Kalijaga Selatan yaitu, STBM Lima Pilar (Sanitasi Total Berbasis Masyarakat) yang terdiri dari pertama, dilarang BAB sembarangan kedua, cuci tangan pakai sabun ketiga, pengelolaan air minum keempat, pengelolaan sampah dengan benar kelima, mengelola 
limbah cair rumah tangga yang aman. Selain dari program STBM, kegiatan kerja bakti sosial juga dapat dilakukan oleh masyarakat Desa Kalijaga Selatan untuk menciptakan lingkungan yang bersih dan tentunya nyaman untuk ditempati.

\section{Kesimpulan}

Masyarakat Desa Kalijaga Selatan Lombok Timur dalam mengelola sampah masih dengan cara sederhana yaitu sampah dikumpulkan, diangkut kemudian dibuang ke TPA (Tempat Pembuangan Akhir) oleh petugas kebersihan. Sampah organik dan anorganik yang tercampur dibuang begitu saja dalam wadah dan kemudian dipindahkan ke tempat pembuangan sampah (TPS) menggunakan mobil setiap hari minggu untuk diangkut menuju TPA. Dalam pengelolaan sampah harus ada kerjasama antara pemerintah dan masyarakat, agar tujuan pengelolaan dapat berhasil sesuai yang diharapkan dalam mendukung terciptanya lingkungan yang sehat dan bersih. Keduanya harus mampu menciptakan sinergi, tanpa melibatkan masyarakat, pemerintah tidak akan dapat mencapai hasil pembangunan secara optimal. Peran serta masyarakat dalam pengelolaan sampah merupakan kesediaan masyarakat untuk membantu berhasilnya program pengembangan pengelolaan sampah sesuai dengan kemampuan setiap orang tanpa berarti mengorbankan kepentingan diri sendiri, tanpa adanya peran dari masyarakat semua program pengelolaan sampah yang direncanakan akan sia-sia. Dampak dari pengelolaan sampah yang kurang baik akan membentuk lingkungan yang kurang menyenangkan bagi masyarakat Desa Kalijaga Selatan. Adapun dampak yang dapat ditimbulkan dengan adanya pengelolaan sampah yaitu dari aspek kesehatan, Lingkungan, ekonomi dan sosial budaya.

\section{Daftar Pustaka}

Alamsyah dan Ratna, (2013), Pilar Dasar Ilmu Kesehatan Masyarakat, Yogyakarta: Nuha Medika.

Ariastuti, R., Astuti, F. B., \& Herawati, V. D. (2015). Berdamai Dengan Sampah. Jurnal DIANMAS, 4(2).

Bara, D., Lasut, J. J., \& Goni, S. Y. (2018). Peran Disiplin Masyarakat dalam menjaga Budaya Hidup Bersih Terhadap Lingkungan (Suatu Studi di Desa Tuabatu Kecamatan Tampan Amma Kabupaten Talaud). HOLISTIK, Journal of Social and Culture, 11(1), 1-20.

Djoyomartono, (2004), Antropologi Kesehatan. Semarang: UPT Unnes Press. 
Hadiwiyoto, S, (1983), Penanganan dan Pemanfaatan Sampah, Jakarta: Yayasan Idayu.

Hasil Observasi, 16 Mei 2019.

Masitoh, D. (2006). Tingkat Kedisiplinan Masyarakat Dalam Menjaga Budaya Hidup Bersih Terhadap Lingkungannya, Studi Kasus Pada Masyarakat Banaran, Kelurahan Sekaran, Kecamatan Gunungpati Semarang, Skripsi, Semarang: Universitas Negeri Semarang.

Monografi Desa Kalijaga Selatan Tahun 2018.

Notoatmodjo, S., (2007), Promosi Kesehatan dan Ilmu Perilaku. Jakarta: Rineka Cipta.

Profil Desa Desa Kalijaga Selatan Tahun 2018.

Proverawati, A dan E, Rahmawati, (2012), Perilaku Hidup Bersih dan Sehat (PHBS), Yogyakarta: Nuha Medika.

Siahaan, N. H. T., (2004), Hukum Lingkungan dan Ekologi Pembangunan, Jakarta: Erlangga.

Slamet, (2002), Kesehatan Lingkungan, Yogyakarta: Gajah Mada University Press.

Sobry, M., \& Naamy, N. (2016). Penguatan ekonomi masyarakat melalui pengelolaan sampah dengan pendekatan keagamaan di Kelurahan Prapen. Transformasi: Jurnal Pengabdian Masyarakat, 12(2), 105-123.

Soekanto, Soerjono, (1983). Teori Sosiologi tentang Perubahan Sosial. Surabaya: Ghalia Indonesia.

Soerjono Soekanto. (2006). Sosiologi Suatu Pengantar, Jakarta: Raja Grapindo Persada.

Sugiyono, (2009), Metode Penelitian Kuantitatif Kualitatif dan $R$ \& D, Bandung: Alfabeta.

Sukardi, (2005). Metodologi Penelitian Pendidikan: Kompetensi dan Praktiknya, Jakarta: Bumi Aksara.

Wawancara, Nurdin A, 28 Mei 2019.

Wawancara, Nurdin B, 25 Mei 2019.

Wawancara, Nurdin C, 25 Mei 2019.

Wawancara, Rusli, 16 Mei 2019.

Wawancara, Takiudin,28 Mei 2019.

Yuliani, F., \& Nazaruddin, N. (2014). Analisis Perilaku Masyarakat dalam Upaya Menciptakan Kebersihan Lingkungan di Kota Pekanbaru (Studi Kasus Kelurahan Simpang Baru), Skripsi, Pekanbaru: Universitas Riau. 